PII: S0045-6535(98)00032-0

$0045-6535 / 98 \$ 19.00+0.00$

\title{
Development of Surrogate Organic Contaminant Parameters for Source Water Quality Standards in Taiwan, ROC
}

\author{
E.E Chang ${ }^{1}$, P.C. Chiang ${ }^{2 *}$, and T.F. Lin $^{3}$ \\ 1: Department of Analytical Chemistry, Taipei Medical College, Taipei, Taiwan, ROC. \\ 2*: Graduate Institute of Environmental Engineering, National Taiwan University, Taipei, Taiwan, ROC. \\ 3: Department of Environmental Engineering, National Cheng-Kung University, Tainan, Taiwan, ROC. \\ (Received in Germany 22 October 1997; accepted 7 January 1998)
}

\begin{abstract}
The objective of this research was to develop a rationale for selecting representative water quality parameters for organic contaminants and microorganisms and determining their respective contaminant level (or regulated value) for the source water quality standards in Taiwan. It was observed that chemical oxygen demand (COD) and total organic carbon (TOC) have strong correlation with $\mathrm{UV}_{254}$ in spite of the raw water which suggests, TOC and COD should be regarded as the surrogate parameters for water quality concerns. It was also proposed to implement $4.0 \mathrm{mg} / \mathrm{L}$ of TOC as a source water criteria at the present time and to adopt a more stringent value $(2.0 \mathrm{mg} / \mathrm{L}$ of TOC) in the next phase (at 2002). The total coliform regulated from 10,000 to 20,000 most probable number (MPN)/100ml level appears to be the most economic and logical way to control trihalomethanes (THM) formation and disinfection efficiency at the water treatment plant in Taiwan. c) 1998 Elsevier Science Ltd. All rights reserved
\end{abstract}

Key Words : Surrogate Parameter, Source Water Quality Standards, Total Organic Carbon, Chemical Oxygen Demand, Most Probable Number

\section{INTRODUCTION}

The quality of the drinking water source in Taiwan is deteriorating rapidly due to water pollution and human activities. Environmental Protection Administration (EPA) of ROC is seeking cost-effective alternatives to meet the drinking water standards. The alternatives include promulgating more stringent regulations to protect the drinking water sources and/or constructing advanced water treatment plants in compliance with drinking water standards. The need of standards to screen source water for the public supply 
use is well recognized. The approach of EPA is to set up a rational standard of source water quality. When the source water quality can not comply with the standards, EPA can push the water industry to refine the existing facilities or install advanced facilities to meet the requirements.

Although the available techniques can treat the raw water to meet the drinking water quality standards, it is wiser to find appropriate water resources prior to introduce the more advanced and complicated treatment techniques. Based on the factual considerations, it might be impossible to find an alternative water resource due to the lack of water resource or the limit of time and budget.

In 1992, the EPA reported the Enforcement Rules of Statute Governing Drinking Water, and Source Water Standards for Public Supplies to proposes some provisions for flexible[1]. Thereafter in 1994, the EPA proposed setting source water quality standards and monitoring frequency for selected the contaminants [2 5]. The objective of this research was to develop a rationale for selecting representative water quality parameters for organic contaminants and microorganisms and determining their respective contaminant level (or regulated value) for the source water quality standards in Taiwan.

\section{FACTORS CONSIDERED IN AMENDING SOURCE WATER QUALITY STANDARDS}

In selecting representative water quality parameters for source water criteria, the following factors must be considered as (1) a representative indicator for water pollution; (2) a long term toxic substance and (3) a feasible or enforceable parameter for command and control. In determining the regulated values for the above representative parameters, (1) the regulated values of other countries, (2) the existing and future drinking water standards, (3) background data of the existing raw water quality, (4) the existing water treatment processes in Taiwan and (5) administrative and analytical problems encountered during execution of the source water criteria must be considered. More detailed considerations on selecting the representative water quality parameters and determining their respective regulated values were summarized as follows:

1.Source Water Quality Standards from Nations around the World

Industrialized countries around the world and many regional or worldwide organizations (such as the USA, EEC and Japan) have already amassed a wealth of information in the scientific communities regarding source water quality $[6,7]$. It is necessary to compare the available numerical limits from various developed countries. Source water criteria from other countries should be tabulated for comparison purposes. As a result, this base-line formation is an important source to be considered in drawing up our national source water quality standards.

2.Domestic Water Quality Background Information of Source Water and Treated Water 
Since the combined indicators for pollution from humans are not directly related to human health and are mainly used for evaluating the extent of water pollution, the limit values for combined indicators should be based on backgrounds, every country establishes its own water quality standards based on special domestic needs and characteristics. A full analysis of relevant background information on source water and treated water is the key factor in understanding how well actual water quality meets established quality standards. Any toxic substances in the source water, which cannot be removed by conventional water treatment processes, must have the same limit as the drinking water standard. The source water criteria for heavy metals from the USA, EC and Japan were determined based on the aforementioned principle $[2 \sim 6,8]$.

\section{Analytical and Monitoring Methods}

The number of regulated chemical, microbiological and physical agents listed in the drinking water quality standards has increased. Significantly, the appropriate analytical and monitoring methods are urgently to be provided by the government agency. When determining the feasibility of anatytical and monitoring methods, consideration must be given to precision, accuracy, representation, comparison, and completeness. Laboratory facilities, operational techniques, and expenditure of both time and money must also be considered before deciding on selecting the best methods in each case.

\section{Water Purification Technologies}

Most water purification facilities in the ROC still rely on traditional treatment methods, i. e., the addition of alum as a coagulant, the use of filtration, and the addition of chlorine as a disinfectant. The efficiency of these methods for meeting the target water quality parameters must be taken into consideration when establishing standards. Purification technologies must be improved in order to raise the quality of water available for consumption. The cost of these technological improvements is an additional factor to be considered in designing new standards.

\section{Cost effectiveness Analysis}

Final source water quality standards may ultimately be established by performing cost-effective analyses. For such an analysis, all life cycle costs, health and portability, and their effects on construction and operating costs must be considered. Operating costs are directly affected by expanded facilities, revised operating procedures, increases in laboratory personnel, the development of new water sources, and the acquisition of land and facilities. In addition, other factors to which monetary worth is attached, such as public opinion. environmental impacts and the effects on the community. must be evaluated. 


\section{DEVELOPMENT OF SOURCE WATER QUALITY STANDARDS}

The above factors must be assessed and carefully considered before new standards are set. At this juncture, source water quality standards in Taiwan are established through a procedure of evaluation by experts and scholars in a technical committee as shown in Figure 1. Since changes to the source water quality standards have far-reaching effects, the technical advisory committee should be solicited to ensure that the new regulations will be through, realistic, and professional. The recommendations of the public and scientific experts are compiled and carefully considered so that there will be greater support behind the new regulations.

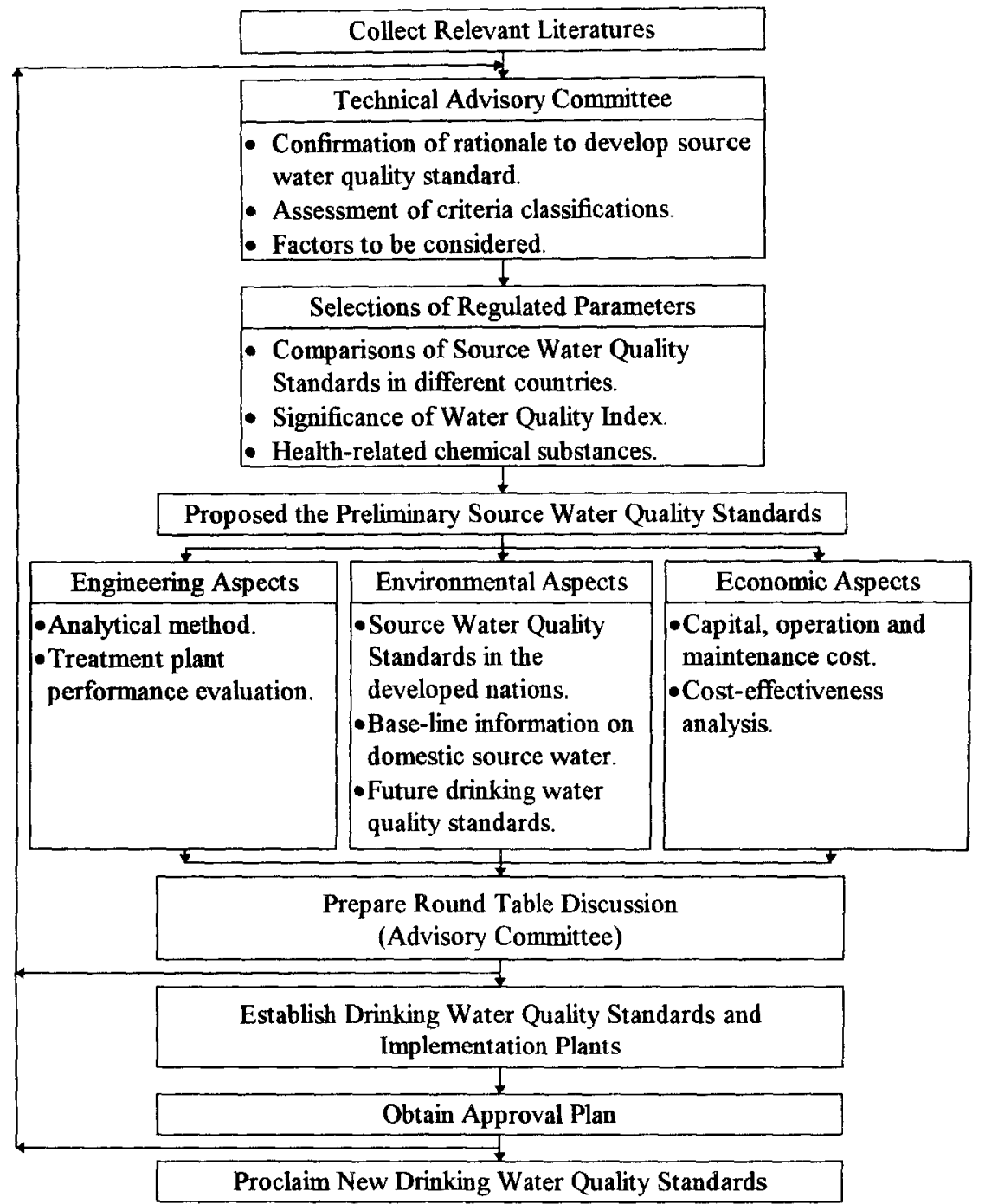

Figure 1. Administrative procedures to Amend Source Water Quality Standards.

In June of 1975, the Council of European Communities (EC) adopted a Council Directive for the Member States concerning the required quality of surface water intended for the abstraction of drinking water. 
The EC Directive divided raw water quality criteria into three classes according to the respective water treatment methods [7]. In April of 1970, the Water Quality Committee of the Japanese Living Environment Council published Water Quality Standards for Water Resources Area to protect raw water quality as well as public health [8]. Similar to the EC Directive, Japanese raw water standards were divided into three classes according to the type of water purification process. In 1971, the United States Public Water Supplies Panel at the request of the USEPA proposed WATER QUALITY CRITERIA for raw water [2 5]. The raw water quality criteria of the USA were established based on water treatment processes which are similar to Class 2 of the EC Directive stated previously.

To simplify the administrative procedure, it is recommended that the implementation of source water criteria be separated into two stages. In the first stage, source water criteria will be established and enforced for a water treatment plant equipped with conventional treatment processes. The conventional water treatment processes consist of coagulation, flocculation, sedimentation and disinfection. Source water criteria established in the first stage will be similar to those of the USEPA except that only representative items with less stringent limits will be adopted due to deterioration of national source water sources. In the second stage, criteria will be established for different classes according to treatment processes. The criteria classifications adopted by Japan and EEC can be used as references in the second stage. The second stage will be started after a satisfactory execution of Stage I criteria.

\section{DETERMINATIONS OF SURROGATE PARAMETERS FOR ORGANIC CONTAMINANTS}

Some organic compounds commonly found in water, such as lignin, tannin, humic substances, and various aromatic compounds, strongly absorb ultraviolet (UV) radiation. UV absorption is a useful surrogate measurement of selected organic constituent in fresh water [9 11]. Strong correlation may exist between UV absorption and organic carbon content, color, and precursors of trihalomethanes (THMs) and other disinfection by-products [12]. Specific absorption, the ratio of UV absorption to organic carbon concentration, has been used to characterize natural organic matter [12 14]

The chemical oxygen demand (COD) is used as a measurement of the oxygen equivalent of the organic matter content in water that is susceptible to oxidation by a strong chemical oxidant, such as nitrogen and inorganics. For samples from a specific source, COD can be related empirically to BOD and total organic carbon (TOC). The COD measurement is very useful for monitoring and control after its correlation has been established.

TOC is a more convenient and direct expression of total organic content than either BOD or COD. Recently, the influent TOC were used to evaluate the effects of DBP control strategies. Philip C. Singer et. al. [15] suggested that chlorine consumption was a reasonably good indicator of the extent of DBP production. 
In our previous study [16 18], it was found that chlorine dose, chlorine contact time, TOC and UV 254 would have significant impact on statistical THM model. As a result, in this research work, it was intended to collect and evaluate surface water quality data, including $\mathrm{Cl}_{2}$ demand, $\mathrm{COD}, \mathrm{TOC}, \mathrm{UV}_{254}$ and DBPFP for establishing suitable source water, from the major water treatment plant in Taiwan.

Raw water samples were collected from six large water treatment plants from Nov. 1994 to May 1997. TOC, $\mathrm{COD}$, chorine demand, $\mathrm{UV}_{254}$, tribalomethane formation potential, and humic substance were conducted in raw water sample. All analysis, useless otherwise noted, were performed according to the $19^{\text {th }}$ edition of Standard Methods.

In Figure 2, the results show that chlorine demand may have much stronger correlation with TOC and COD than either $U_{254}$ or humic substance $(r<0.60)$. Chlorine can add to olefins and other double-bondcontaining organics, these reactions were related to $U V_{254}$ and humic substance. However, chorine can also oxidize the reduced inorganic species and substitute chemical substrates and resulted in having non-significant correlation of $\mathrm{UV}_{254}$ and humic substance. In Figure 3, it was evident that the correlation existing between total organic carbon with $U_{254}$ and humic substance which could be interpreted by the fact that the constant portions of double-bond or aromatic compounds to the organics in the raw water were observed.
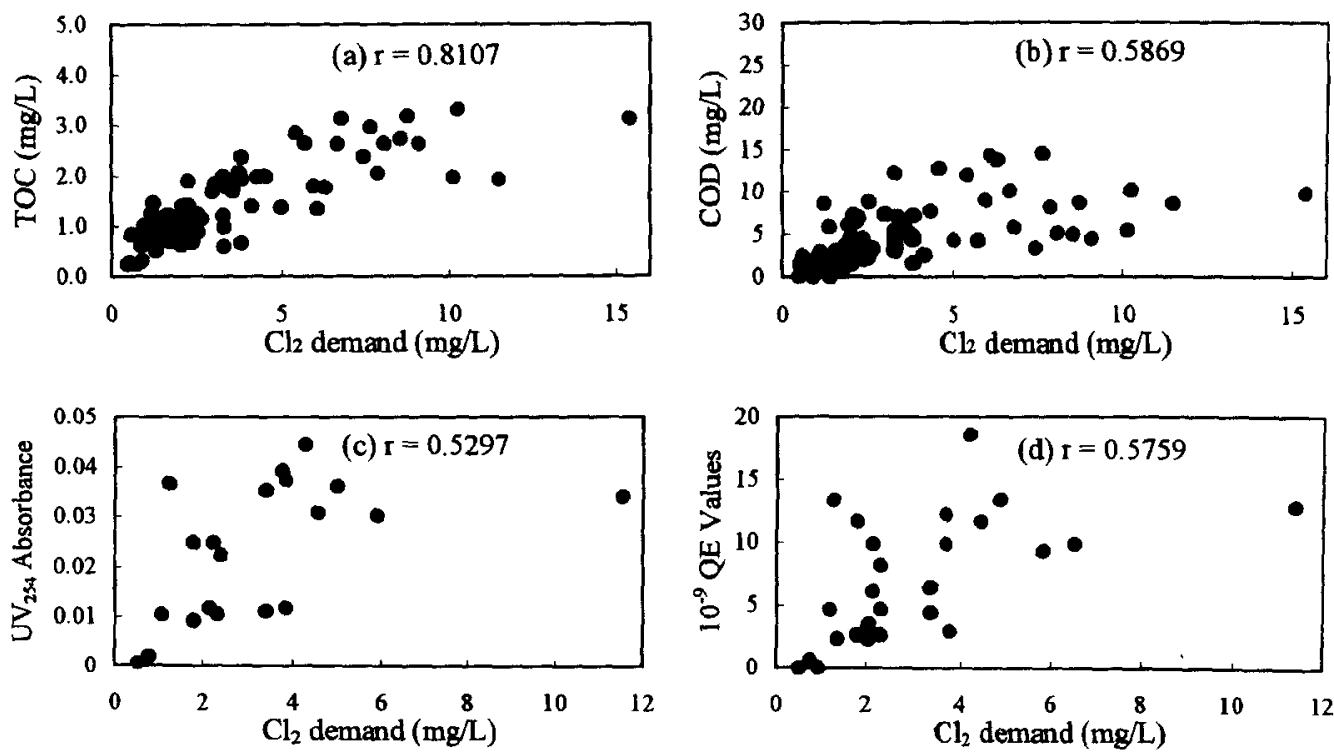

Figure 2. Results of correlation between chlorine demand and other parameters: (a) TOC, (b) COD, (c)

$$
\mathrm{UV}_{254} \text {, (d) humic substance. }
$$

Figure 4 also present COD has strong correlation with $U_{254}$ (or humic substance) in spite of the raw water which suggest, COD should be regarded as a surrogate parameter for water quality concerns. 

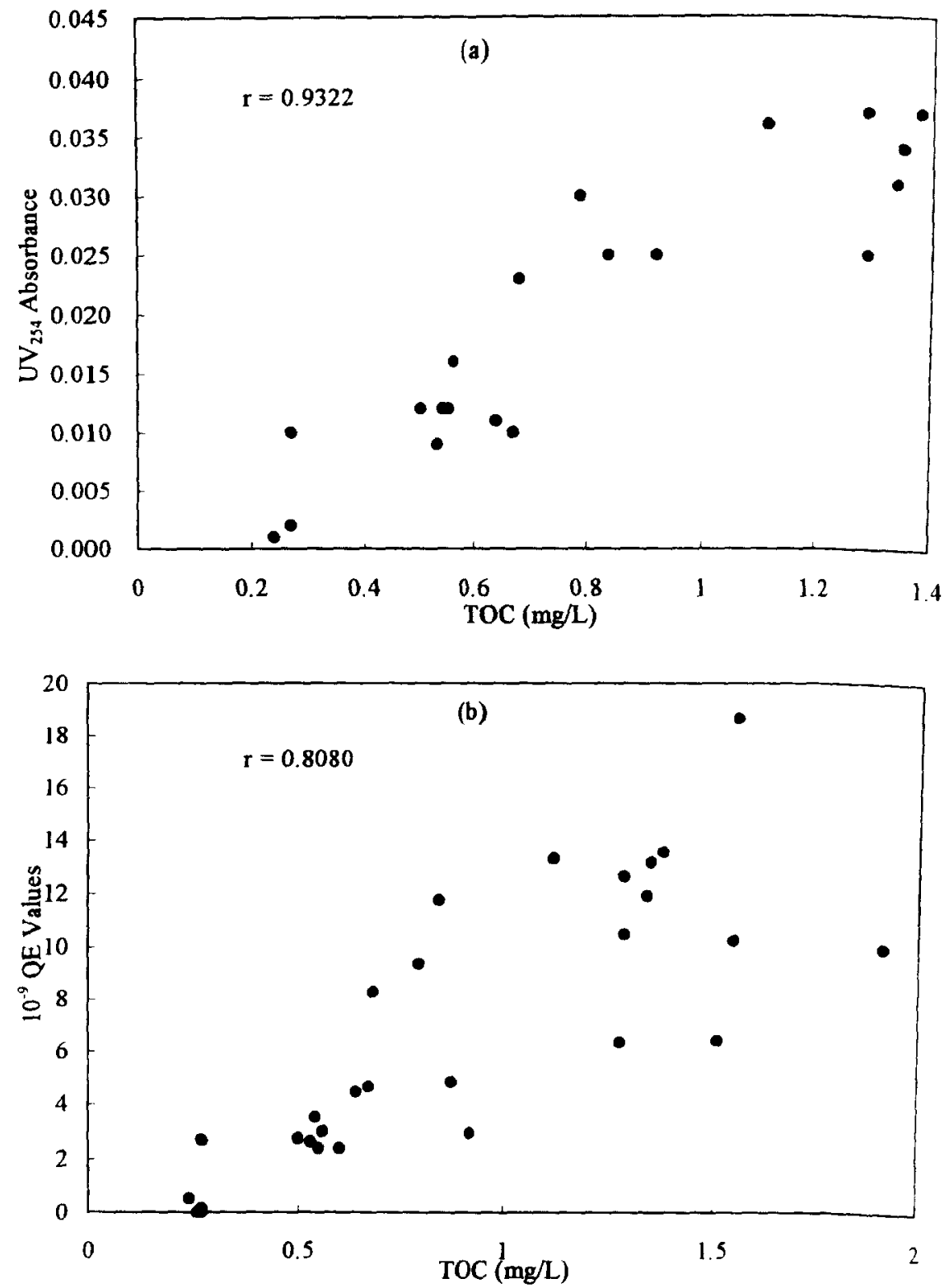

Figure 3. Results of correlation between total organic carbon and other parameters:

(a) $\mathrm{UV}_{254}$, (b) humic substance. 

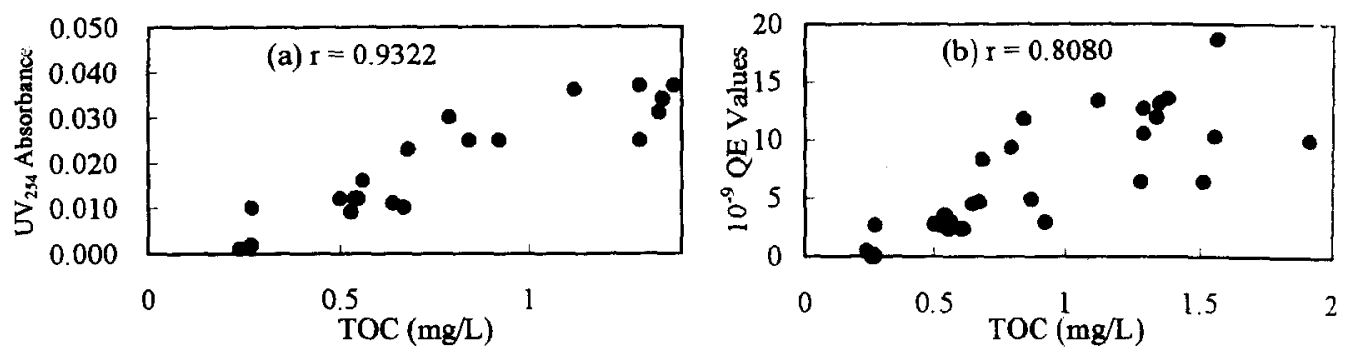

Figure 3. Results of correlation between total organic carbon and other parameters: (a) UV254, (b) humic substance.
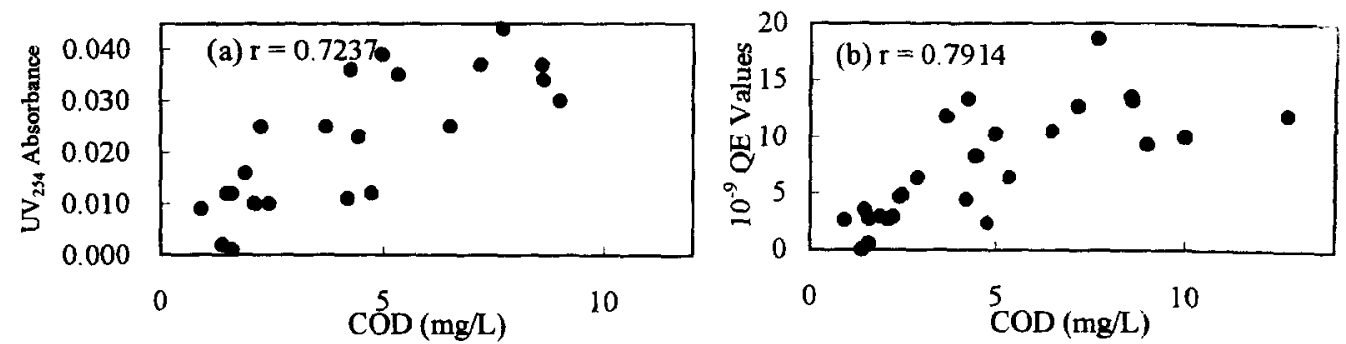

Figure 4. Results of correlation between chemical oxygen demand and other parameters: (a) $U V_{254, \text {, (b) humic }}$ substance.

\section{DETERMINATIONS OF REGULATED STANDARDS FOR COD AND TOC}

Total coliforms, COD and TOC are potential contaminants contributed by microbial communities and human activities. The criteria or regulated standards for these surrogated parameters, i.e., total coliforms, COD and TOC have to be comprehensively evaluated based on the nationally and internationally available information. Table 1 and Figure 2 present the results of TOC, chlorine demand and COD analyses in source water measured at the Taipei Municipal Water Treatment Plant and the major water treatment plants in Taiwan Province from 1995 to 1997, respectively. It was observed approximately $90 \%$ of TOC were less than $3,0 \mathrm{mg} / \mathrm{L}$ source waters exhibited a higher chlorine demand $(>5 \mathrm{mg} / \mathrm{L}$ ), there also existed TOC concentrations greater than $2.0 \mathrm{mg} / \mathrm{L}$ which normally possess a higher potential for forming THMs as shown in Figure 5 .

Figure 6 depicts the relationship between TOC and THM formation at fixed chlorine dose $(2.0 \mathrm{mg} / \mathrm{L})$. Results indicate that the formation of THMs increases with TOC [19]. Moreover, at a contact time of 40 minutes, when TOC $=4 \mathrm{mg} / \mathrm{L}$, the concentration of THMs is approximately double the concentration when TOC $=3 \mathrm{mg} / \mathrm{L}$. To stay within the allowable level of THM for ROCEPA drinking water quality standard (100 $\mu \mathrm{g} / \mathrm{L}$ ), the TOC concentration prior to the application of disinfectant should be kept under $3 \mathrm{mg} / \mathrm{L}$.

Recently, the USEPA Disinfectant/Disinfection by-product rule requires the use of enhanced coagulation by utilities to treat surface water containing TOC concentrations above a certain level. The Information Collection Rule also suggested that TOC measurement in the bench or pilot-scale studies on 
granular activated carbon or membrane filtration must be conducted to determine whether they are subject of performing the disinfection by-products precursors removal treatment. As a result, the regulated limit of TOC parameter for disinfection by-products concern was set at $4.0 \mathrm{mg} / \mathrm{L}$ (up-to-date) and $2.0 \mathrm{mg} / \mathrm{L}$ (at 2002), respectively, which would provide a guideline for ROCEPA [20] to assess her enforceable potency by promulgating these standards. With this available back-ground information obtain from our three years of research work, it might be proposed to adopt $4.0 \mathrm{mg} / \mathrm{L}$ of TOC as a source water criteria at the present time and to adopt more stringent value $(2.0 \mathrm{mg} / \mathrm{L}$ of TOC $)$ in the next phase as stated in Table 2.

Table 1 Analysis of TOC, COD and $\mathrm{Cl}_{2}$ demand in Raw Water Quality from October 1995 to May 1997.

\begin{tabular}{|c|c|c|c|c|c|c|c|c|c|c|}
\hline \multirow[t]{2}{*}{ Plants } & \multicolumn{3}{|c|}{ Average (mg/L) } & \multicolumn{3}{|c|}{ Range (mg/L) } & \multicolumn{3}{|c|}{ RSD (\%) } & \multirow[t]{2}{*}{$\mathbf{n}$} \\
\hline & TOC & COD & $\begin{array}{c}\mathrm{Cl}_{2}^{*} \\
\text { demand }\end{array}$ & TOC & COD & $\begin{array}{c}\mathrm{Cl}_{2} \\
\text { demand }\end{array}$ & TOC & COD & $\begin{array}{c}\mathrm{Cl}_{2}{ }^{*} \\
\text { demand }\end{array}$ & \\
\hline $\mathrm{C}$ & 1.32 & 4.88 & 2.96 & $0.59 \sim 2.73$ & $1.1 \sim 14.32$ & $0.61 \sim 8.53$ & 36.70 & 25.66 & 64.70 & 22 \\
\hline U & 0.83 & 2.19 & 1.89 & $0.14 \sim 1.35$ & $N^{* *}-4.74$ & $0.90-3.36$ & 25.52 & 53.99 & 33.39 & 19 \\
\hline L & 2.58 & 8.68 & 7.12 & $1.42 \sim 7.20$ & $2.98 \sim 42.58$ & $2.31 \sim 15.40$ & 45.42 & 94.91 & 43.79 & 22 \\
\hline $\mathbf{N}$ & 1.10 & 3.35 & 2.65 & $0.63 \sim 3.16$ & $1.49 \sim 8.68$ & $1.15 \sim 8.74$ & 72.28 & 72.18 & 91.90 & 9 \\
\hline$S$ & 1.00 & 3.33 & 1.72 & $0.44 \sim 1.90$ & $1.90-6.96$ & $1.18 \sim 2.35$ & 42.37 & 55.85 & 26.25 & 9 \\
\hline D & 2.69 & 14.48 & 3.41 & $4.96-58.58$ & $4.96 \sim 58.58$ & $1.27 \sim 6.86$ & 82.17 & 124.47 & 51.68 & 8 \\
\hline
\end{tabular}

* : Contact time $\left(\mathrm{Cl}_{2}\right.$ demand $): 24$ hours

** : MDL (COD) : $0.85 \mathrm{mg} / \mathrm{L}$

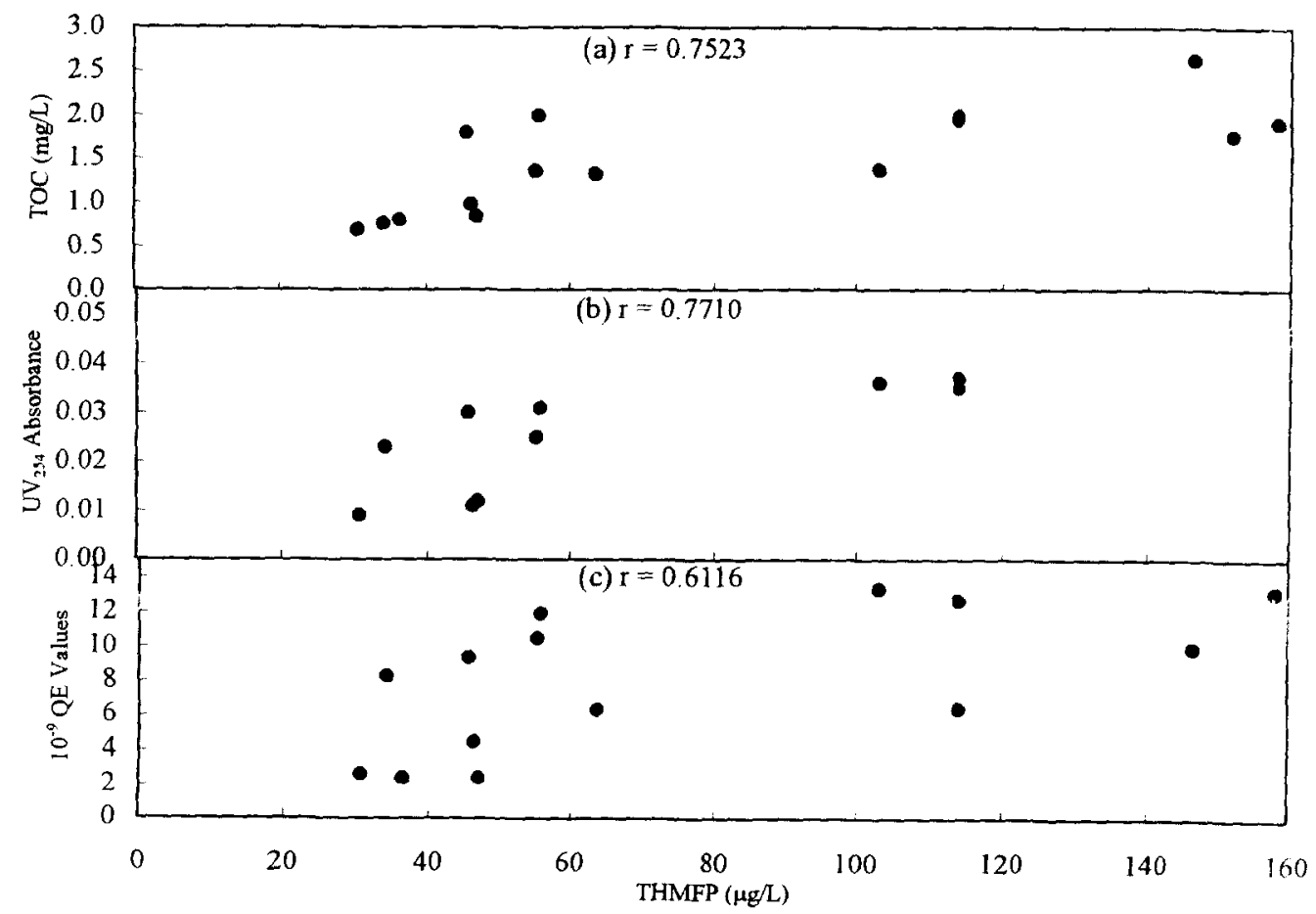

Figure 5. Results of correlation between THMFP and other parameters: (a) TOC, (b) UV $\mathrm{UV}_{254}$, (c) humic substance. 


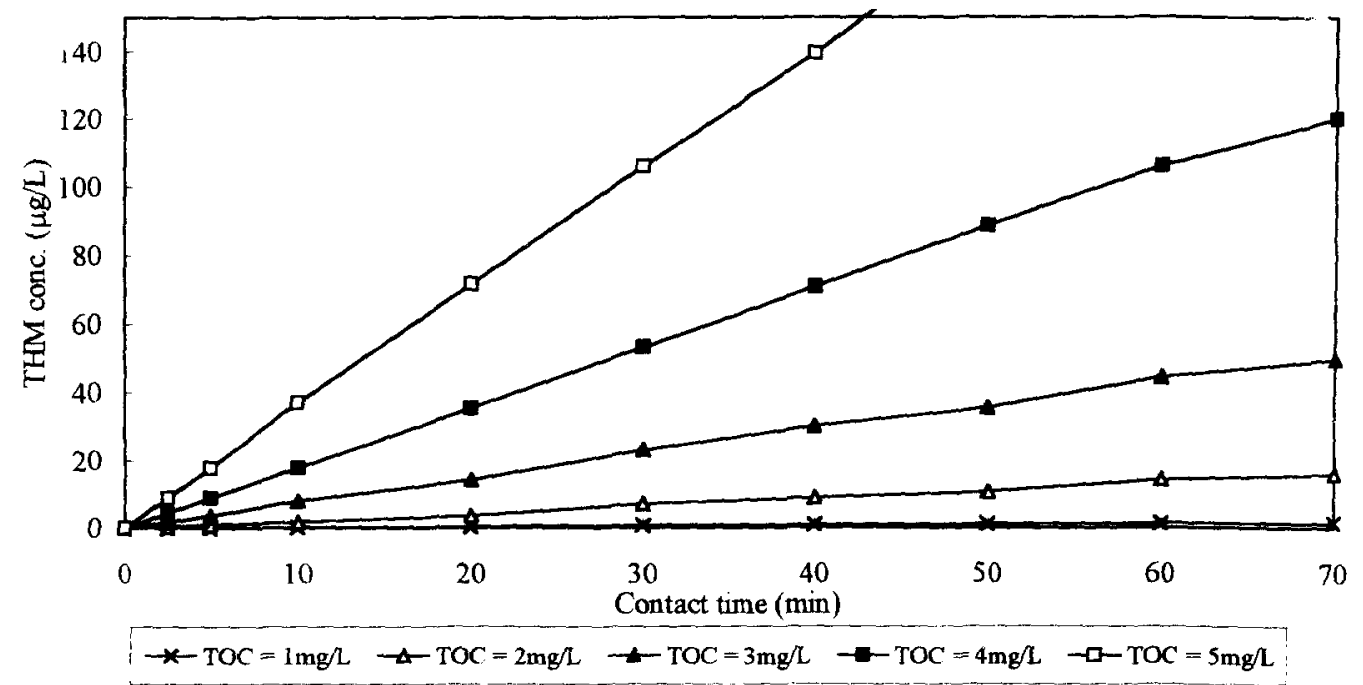

Figure 6. Effective of TOC on THM formation for applied chlorine dose $=2.0 \mathrm{mg} / \mathrm{L}$ and the rectangul: chlorine contact chamber of $\mathrm{L} / \mathrm{W}$ ratio $=20$.

In order to make a compromise between THM formation and disinfection efficiency, the allowable level of THMs was set at $0.1 \mathrm{mg} / \mathrm{L}$ (including chloroform, bromodichloromethane, dibromochloromethane and bromoform), a level which is based on the drinking water standards of ROCEPA. Acceptable disinfection efficiency was set at $99.99 \%$ inactivation of the total coliform count (the average level of coliform measured in raw water is about $10,000 \mathrm{MPN} / 100 \mathrm{~mL}$ ), which would also meet the ROCEPA standards. In Table 3, a 99.99\% kill is achieved at those conditions shown within the framed region. The THM concentration and disinfection efficiency associated with a given contact time, and applied chlorine dose were also presented in Table 3. This information can be used to determine the applied chlorine dose needed to meet a specified degree of inactivation and THM level (P.C. Chiang et. al., 1997).

It is noted that under these conditions, the plant is able to maintain an acceptable level of residual chlorine $(0.5 \mathrm{mg} / \mathrm{L})$ and THMs $(60 \mu \mathrm{g} / \mathrm{L})$ which is a more stringent standard in the future. This evidence provides the referenced background information to set the regulated value of total coliform for ROC source water quality as presented in Table 4 . Similar discussions and methodologies to generate source water criteria for the COD water quality parameters were shown in Table 5 .

\section{CONCLUSIONS AND RECOMMENDATIONS}

Due to the unique geographical and socio-economical situations in Taiwan, its raw water resources are prone to various contaminants. It is necessary to establish and enforceable buffer zone for source water so as to minimize non-point source pollution. The other measure is to use groundwater recharge as a means to prepurify waters of high levels of contaminants. In addition, the Environmental Protection Administration (EPA) 
of ROC has decided to promulgate more stringent regulations to protect the drinking water sources and/or construct advanced water treatment plants to comply with the requirements of drinking water standards. Therefore, it is necessary to develop the surrogate organic concentration parameters and their respectively regulated values for source water quality standards.

Table 2 Background Information Pertaining to Determination of Source Water Quality Standard for TOC.

\begin{tabular}{|c|c|c|c|c|c|}
\hline Item & $\begin{array}{c}\text { Referenced } \\
\text { Criteria }\end{array}$ & $\begin{array}{l}\text { Sources of } \\
\text { the Criteria }\end{array}$ & $\begin{array}{c}\text { Water Quality } \\
\text { Statistics } \\
\text { in Taiwan, ROC }\end{array}$ & $\begin{array}{c}\text { Evaluations of } \\
\text { Water } \\
\text { Treatment Facilities }\end{array}$ & $\begin{array}{l}\text { Discussions and } \\
\text { Recommendations }\end{array}$ \\
\hline \multirow{2}{*}{$\begin{array}{c}\text { Total } \\
\text { Organic } \\
\text { Carbon, } \\
\text { (TOC, mg/L) }\end{array}$} & 2 & $\begin{array}{l}\text { Required by } \\
\text { US EAP } \\
\text { ICR Rule, } \\
\text { effective } \\
2002 .\end{array}$ & $\begin{array}{l}\text { 1. All raw water } \\
\text { samples of Taiwan } \\
\text { Water Plant met } \\
\text { this criteria. } \\
\text { 2. } 20 \% \text { of TOC } \\
\text { samples exceeding } \\
\text { this vahuel. }\end{array}$ & \multirow{2}{*}{\begin{tabular}{|l} 
1. It is still uncertain \\
that conventional \\
water treatment \\
processes are \\
effective in TOC \\
removal. \\
2. According to the \\
$1995-1997$ study \\
plan for six major \\
water plants, \\
approximately $10-$ \\
$65 \%$ of TOC \\
removal efficiency \\
was estimated for \\
conventional \\
water treatment \\
processes.
\end{tabular}} & $\begin{array}{l}\text { 1. It is doubtful that the } \\
\text { laboratories in the water } \\
\text { plants and local } \\
\text { environmental agencies } \\
\text { are capable of } \\
\text { performing the TOC } \\
\text { test. }\end{array}$ \\
\hline & 4 & $\begin{array}{l}\text { Currently } \\
\text { required by } \\
\text { US EPA } \\
\text { ICR Rule. }\end{array}$ & $\begin{array}{l}\text { 1. All raw water } \\
\text { samples of Taiwan } \\
\text { Water Plant met } \\
\text { this criteria. } \\
\text { 2. } 3 \% \text { of TOC } \\
\text { samples exceeding } \\
\text { this value }^{t}\end{array}$ & & $\begin{array}{l}\text { 2. The TOC values of raw } \\
\text { water from Cheng-Ching } \\
\text { Lake Water Plant were } \\
\text { mostly less than } 4 \mathrm{mg} / \mathrm{L} \text {, } \\
\text { but } \mathrm{THM} \text { were mostly } \\
\text { higher than } 40 \mu \mathrm{g} / \mathrm{L} \text {. } \\
\text { 3. It is recommended to } \\
\text { adopt } 4 \mathrm{mg} / \mathrm{L} \text { as national } \\
\text { criteria. }\end{array}$ \\
\hline
\end{tabular}

Statistical values of samples taken from 6 water plants between 1994-1997 and analyzed for TOC $(n=37)$.

Table 3 Disinfection Efficiency and THM Formation During Chlorination at TOC $=3 \mathrm{mg} / \mathrm{L}$.

\begin{tabular}{cccc}
\hline Contact time (min) & \multicolumn{3}{c}{ Applied Chlorine (mg/L) } \\
\cline { 2 - 4 } & 0.5 & 1.0 & 1.5 \\
\hline \multirow{2}{*}{20} & $99.40^{*}$ & 99.96 & 99.98 \\
& $(3.54)^{* *}$ & $(7.08)$ & $(8.85)$ \\
30 & 99.94 & 99.98 & 99.99 \\
& $(5.22)$ & $(10.45)$ & $(13.06)$ \\
40 & 99.97 & 99.99 & 99.99 \\
& $(6.85)$ & $(13.70)$ & $(17.13)$ \\
50 & 99.98 & 99.99 & 99.99 \\
& $(8.42)$ & $(16.85)$ & $(21.06)$ \\
\hline
\end{tabular}

* : Disinfection efficiency in $\%$ kill.

** : The numerical value in the parenthesis denotes the THM formation in $\mathrm{mg} / \mathrm{L}$. 
Table 4 Background Information Pertaining to Determination of Source Water Quality Standard for Total Coliform.

\begin{tabular}{|c|c|c|c|c|c|}
\hline Item & $\begin{array}{c}\text { Referenced } \\
\text { Criteria }\end{array}$ & $\begin{array}{c}\text { Sources of the } \\
\text { Criteria }\end{array}$ & $\begin{array}{c}\text { Water Quality } \\
\text { Statistics } \\
\text { in Taiwan, ROC } \\
\end{array}$ & $\begin{array}{c}\text { Evaluations of } \\
\text { Water } \\
\text { Treatment Facilities }\end{array}$ & $\begin{array}{l}\text { Discussions and } \\
\text { Recommendations }\end{array}$ \\
\hline \multirow{3}{*}{$\begin{array}{c}\text { Total } \\
\text { Coliform, } \\
\text { (MPN/100mL) }\end{array}$} & 500 & \begin{tabular}{|l}
${ }^{*}$ Category B of \\
ROC National \\
Water \\
Classification \\
${ }^{*}$ Canadian raw \\
water criteria \\
${ }^{*}$ Class III of \\
Japanese raw \\
water criteria
\end{tabular} & $\begin{array}{l}\text { Approximately } 20 \% \\
\text { of major raw water } \\
\text { sources in Taiwan } \\
\text { cannot meet this } \\
\text { criteria (based on the } \\
\text { annual average value) }\end{array}$ & \multirow{3}{*}{\begin{tabular}{|l} 
1. Effectively \\
removed by \\
filtration \& \\
disinfection \\
processes. \\
2. Removal \\
efficiency \\
enhanced by pre- \\
chlorination. \\
3. 97.3\% of water \\
plants in Taiwan \\
equipped with \\
disinfection \\
process, $77 \%$ of \\
water plants (using \\
surface water \\
source) equipped \\
with filtration and \\
disinfection \\
processes.
\end{tabular}} & \multirow{3}{*}{$\begin{array}{l}\text { 1. If } 20,000 \mathrm{MPN} / 100 \\
\text { mL is adopted as } \\
\text { national criteria, it } \\
\text { may require } \\
\text { additional } \\
\text { disinfectant resulting } \\
\text { in increase of } \\
\text { disinfection by- } \\
\text { products in the. } \\
\text { finishing water. } \\
\text { 2. If } 5,000 \text { MPN/100 } \\
\text { mL is adopted, many } \\
\text { raw water sources } \\
\text { cannot meet in this } \\
\text { criteria resulting in } \\
\text { compliance } \\
\text { problems. Therefore, } \\
10,000 \text { MPN/100 } \\
\text { mL is recommended } \\
\text { at the present time }\end{array}$} \\
\hline & 10,000 & $\begin{array}{l}* \text { Category B of } \\
\text { ROC National } \\
\text { Water } \\
\text { Classification } \\
\text { (ROC) } \\
\end{array}$ & $\begin{array}{l}\text { Approximately } 15 \% \\
\text { of major raw water } \\
\text { sources in Taiwan } \\
\text { cannot meet this } \\
\text { criteria (based on the } \\
\text { annual average value) }\end{array}$ & & \\
\hline & 20,000 & $\begin{array}{l}\text { Raw water } \\
\text { criteria from } \\
\text { USA }\end{array}$ & $\begin{array}{l}49 \text { major raw water } \\
\text { sources in Taiwan } \\
\text { meet this criteria } \\
\text { (based on annual } \\
\text { average value) }\end{array}$ & & \\
\hline
\end{tabular}

In this investigation, it was observed that COD and TOC have strong correlation with $U_{254}$ (humic substance and chlorine demand) in spite of the raw water which suggests, TOC and COD should be regarded as the surrogate parameters for water quality concerns. With this currently available information, it was proposed to implement $4.0 \mathrm{mg} / \mathrm{L}$ of TOC as a source water criteria at the present time and to adopt a more stringent value $(2.0 \mathrm{mg} / \mathrm{L}$ of TOC) in the next phase (at 2002). The total coliform regulated from 10,000 to $20,000 \mathrm{MPN} / 100 \mathrm{ml}$ level appears to be the most economic and logical way to control THM formation and disinfection efficiency at the water treatment plant in Taiwan. 
Table 5 Background Information Pertaining to Determination of Source Water Quality Standard for COD.

\begin{tabular}{|c|c|c|c|c|c|}
\hline Item & $\begin{array}{c}\text { Referenced } \\
\text { Criteria } \\
\end{array}$ & $\begin{array}{l}\text { Sources of } \\
\text { the Criteria }\end{array}$ & $\begin{array}{c}\text { Water Quality Statistics } \\
\text { in Taiwan, ROC } \\
\end{array}$ & $\begin{array}{c}\text { Evaluations of Water } \\
\text { Treatment Facilities }\end{array}$ & $\begin{array}{c}\text { Discussions and } \\
\text { Recommendations } \\
\end{array}$ \\
\hline \multirow{3}{*}{$\begin{array}{l}\text { Chemical } \\
\text { Oxygen } \\
\text { Demand, } \\
\text { (COD, mg/L) }\end{array}$} & 20 & $\begin{array}{l}\text { Class } 1 \text { A of } \\
\text { France raw } \\
\text { water criteria }\end{array}$ & $\begin{array}{l}\text { 1. Based on anmual } \\
\text { average, approximately } \\
10 \% \text { of major raw } \\
\text { water sources in } \\
\text { Taiwan exceeding this } \\
\text { value } \\
\text { 2. } 4 \% \text { of COD samples } \\
\text { exceeding this value }\end{array}$ & \multirow{3}{*}{$\begin{array}{l}\text { 1. It is still uncertain } \\
\text { that conventional } \\
\text { water treatment } \\
\text { processes are } \\
\text { effective in COD } \\
\text { removal. } \\
\text { 2. According to the } \\
1995-1997 \text { study } \\
\text { plan, approximately } \\
20-70 \% \text { of COD } \\
\text { removal was } \\
\text { estimated for three } \\
\text { major water plants } \\
\text { in north, middle and } \\
\text { south Taiwan. }\end{array}$} & \multirow{3}{*}{$\begin{array}{l}\text { 1. The COD value } \\
\text { of raw water s } \\
\text { closely related to } \\
\text { the chlorine } \\
\text { demand. } \\
\text { 2. In most cases, the } \\
\text { raw water quality } \\
\text { in Taiwan can } \\
\text { meet any of these } \\
\text { three values. } \\
\text { 3.It is recommended } \\
\text { to adopt } 25 \text { mg/L } \\
\text { as raw water } \\
\text { criteria for surface } \\
\text { sources at the } \\
\text { present time and } \\
\text { to adopt a more } \\
\text { stringent value } \\
\text { (20 mg/L) in the } \\
\text { next phase. } \\
\text { (criteria for } \\
\text { groundwater } \\
\text { sources will be } \\
\text { evaluated } \\
\text { separatedly) }\end{array}$} \\
\hline & 25 & $\begin{array}{l}\text { Class } 2 \mathrm{~A} \text { of } \\
\text { France raw } \\
\text { water criteria }\end{array}$ & $\begin{array}{l}\text { 1. Based on annual } \\
\text { average, approximately } \\
6 \% \text { of major raw water } \\
\text { sources in Taiwan } \\
\text { exceeding this value ( } 3 \\
\text { plants) } \\
\text { 2. } 4 \% \text { of COD samples } \\
\text { exceeding this value }\end{array}$ & & \\
\hline & 30 & \begin{tabular}{|l|} 
Class A3 of \\
EC raw \\
water criteria \\
\end{tabular} & $\begin{array}{l}\text { 1. Based on annual } \\
\text { average, approximately } \\
4 \% \text { of major raw water } \\
\text { sources in Taiwan } \\
\text { exceeding this value } \\
\text { 2. } 4 \% \text { of COD samples } \\
\text { exceeding this value }\end{array}$ & & \\
\hline
\end{tabular}

Statistical values of samples taken from 6 water plants between 1994-1997 and analyzed for COD $(n=47)$.

\section{REFERENCES}

1. J.H. Yeh, M.H. Hsu, E.E. Chang, and C.P. Huang, Development of Statute Governing Drinking Water and Strategic Plan for Driuking Water Research in ROC. Proceeding $3^{\text {rd }}$ International Workshop on Drinking Water Quality Management and Treatment Technology, March 5-6, 1997, Taiwan, ROC. 103-117, (1997).

2. USEPA. Disinfectants/Disinfection By-Products Rule. July 29, (1994).

3. USEPA. Enhanced Surface Water Treatment Rule. July 29, (1994).

4. USEPA. Information Collection Rule. Feb. 10, (1994).

5. USEPA. Optimizing Water Treatment Plant Performance using the Composite Correction Program. EPA/625/6-91/027. Feb. (1991). 
6. Council of the European Communities. Council Directive of 16 June 1975 Concerning the Quality Required of Surface Water Intended for the Abstraction of Drinking Water in the Member States. Official Journal of the European Communities, OJ No L 194, 25, 7. 1975, 26-31, Luxembourg. (1975).

7. National Academy of Sciences - National Academy of Engineering. Water Quality Criteria. A Report of the Committee on Water Quality Criteria, at the Request of and Funded by the Environmental Protection Agency, Washington, D.C., (1972).

8. Institute of Public Health. Water Quality Standards. Tokyo, Japan. (1970).

9. RA. Dobbs, R.H. Wise, and RB. Dean, The Use of Ultraviolet Absorbance for Monitoring the Total Organic Carbon of Water and Wastewater. Water Res. 6, 1173, (1972).

10. A.L. Wilson, Determination of Fulvic Acids in Water. J. Appl. Chem. 9, 501, (1959).

11. A.L. Copper, and J.C. Young, Chemical Non-specific Organic Analysis. In R.A. Minear and L. Keith, eds. Water Analysis, Vol. 3., Academic Press, New York, N.Y. (1984).

12. J.K. Edzwald, W.C. Becker, and K.L. Wattier, Surrogate Parameters for Monitoring Organic Matter and THM Precursors. J. Amer. Water Work Assoc. 77, 122, (1985).

13. E.M. Thurman, Organic Geochemistry of Natural Waters. Martinus Nijhoff/Dr. W. Junk Publishers, Dordrecht, Netherlands. (1985).

14. D.M. Owen, G.L. Amy, and Z.K. Chowdhury, Characterization of Natural Organic Matter and Its Relationship to Treatability, 90631, AWWA Research Foundation and American Water Works Assoc., Denver, Colo. (1993).

15. P.C. Singer, A. Obolensky, and A. Greiner, DBPs in Chlorinated North Carolina Drinking Waters. $J$. Amer. Water Works Assoc. 84, 83, (1995).

16. E.E. Chang, S.H. Chao, P.C. Chiang, and J.F. Lee, Effects of Chlorination on THMs Formation in Raw Water. Toxicol. Environ. Chem., 56, 211-225, (1996).

17. E.E. Chang, P.C. Chiang, and Y.C. Chou, Drinking Water Quality Standards: Establishment and Implementation. Proceeding of $2^{\text {nd }}$ International Workshop on Drinking Water Quality Management and Treatment Technology, May 9-10, 1996, Taiwan, ROC (1996).

18. E.E. Chang, Rational Study on Establishing National Source Water Quality Standards. ROC EPA-86J102-09-07 (1997).

19. P.C. Chiang, E.E. Chang, Y.W. Ko, and J.C. Lou, Balancing Disinfection Efficiency and THM Formation During Chlorination: Theoretical Considerations. Can. J. Chem. Eng, 75, (1997).

20. ROCEPA. Water Pollution Control Act. May 6, 1991. 